\title{
Penoscrotal elephantiasis, diagnosis and therapeutic care: Case series and literature review
}

\author{
S. Mellas ${ }^{2, ~ *, ~ O . ~ R i y a c h ~}{ }^{1}$, , M. Ahsaini ${ }^{1}$, Y. Ahallal ${ }^{1}$, M. F. Tazi ${ }^{1}$, J. E. El Ammari ${ }^{1}$, A. Khallouk ${ }^{1}$,
} M. J. El Fassi ${ }^{1}$, M. H. Farih ${ }^{1}$

${ }^{1}$ Department of urology, Hassan II University Hospital Center -FEZ, MOROCCO

${ }^{2}$ Department of Anatomy, Faculty of Medicine and Pharmacy of FEZ, MOROCCO

Email address:

riyach2@hotmail.com (O. Riyach)

\section{To cite this article:}

S. Mellas, O. Riyach, M. Ahsaini, Y. Ahallal, M. F. Tazi, J. E. El Ammari, A. Khallouk, M. J. El Fassi, M. H. Farih. Penoscrotal Elephantiasis, Diagnosis and Therapeutic Care: Case Series and Literature Review. Journal of Surgery. Vol. 2, No. 3, 2014, pp. 46-49. doi: $10.11648 /$ j.js.20140203.13

\begin{abstract}
Background: Penoscrotal Elephantiasis is a rare disease outside areas where filariasis is endemic. It is a benign disease but can become disabling in that it can make sexual relations difficult and sometimes even affect urination. We report four cases of primitive penoscrotal elephantiasis treated with complete surgical resection of pathological tissue and penoscrotal reconstruction, with good functional and aesthetic results. We update, through our own experience and a review of the literature, aspects of the diagnostic and therapeutic care of penoscrotal elephantiasis.
\end{abstract}

Keywords: Elephantiasis, Filariasis, Penoscrotal Reconstruction

\section{Introduction}

The penoscrotal Elephantiasis is an increase - sometimes a huge - of the scrotum's volume; it is characterized by its rarity outside endemic filariasis, by its spectacular appearance and its psychological impact.

This disease occurs usually in filarial endemic countries; a part from the latter, it is often secondary to bacterial etiology, which is associated with a urethral stenosis, a surgery or pelvic radiotherapy, and rarely, it is primitive or idiopathic.

Besides, the purpose of this study is to report the clinical symptoms and the treatment of this particular disease. Our study involved four patients who were treated surgically with good outcomes as well as satisfactory functional and aesthetic results.

\section{Cases Presentation}

\subsection{Case Presentation: 1}

A 63 year old Berber man, farmer and father of seven children, consulted for major chronic lymphedema of the penis and the scrotum that lasted for three years, making both walking and the sexual activity difficult. The patient had a history of recurrent urethritis. In addition, we have not noted a history of living in endemic filariasis region, scrotal trauma, surgery or pelvic radiotherapy, or other antecedents (heart failure, renal failure, hypoproteinemia). The clinical examination showed penoscrotal elephantiasis respecting the glans and both lower limbs, as well as indurations of the urethra palpation, and the rest of the examination was normal.

Chlamydia serology, made in the context of searching for lymphogranuloma venereum was positive, microfilaria research in the blood was negative, with no nephrotic syndrome, and the exploration of the vascular axis of the lower limbs was normal.

Retrograde and Voiding Urethrocystography was made, and it showed a short and tight stricture of the bulbous urethra.

Finally, we have chosen the diagnosis of penoscrotal elephantiasis secondary to bacterial infection by Chlamydia associated with urethral stricture.

The surgical treatment consisted in a resection of the scrotal elephantiasis with sparing the healthy scrotal tissue at the root that was used for scrotal reconstruction; we have also performed an endoscopic urethrotomy for urethral stricture. Then, the inflammatory origin was concluded using the histological study. 
Besides, there were no postoperative events, the aesthetic and functional results were very good, with a decline of eight months.

\subsection{Case presentation: 2}

A 69 year old Arab man, with no antecedent, presented with a ten year history of progressive increase of the scrotal volume.

In fact, during the clinical examination, we found in a scrotum's diameter of $30 \mathrm{~cm}$, with thickened skin and buried penis glove finger, the research of microfilaria in the blood and the Chlamydia serology were both negative; the exploration of the vascular axis of the lower limbs was normal, and the abdominopelvic CT scan showed a thickened scrotal wall, with no obstructive cause.

In addition, the surgical excision of the purse and the skin covering the root of the penis was performed with aesthetic reconstruction covering testicles; four years later, the follow-up examinations showed no abnormality.

Also, the pathological examination of the surgical specimen revealed a significant edema of the deep dermis, associated with an inflammatory infiltration in the dermis, suggesting a non-filarial idiopathic penoscrotal lymphoedema.

\subsection{Case Presentation: 3}

A 58 year old saharian male, shoemaker, with a two year history of significant chronic lymphedema of the penis and the scrotum. On the physical examination, the purse had a diameter of $21 \mathrm{~cm}$; the penis was enlarged, making $15 \mathrm{~cm}$ long and $8 \mathrm{~cm}$ wide, there was also a clear demarcation between the the healthy skin and the affected one. On palpation, the mass was soft, but it was impossible to identify the Testicles embedded in the diseased tissue.

The history revealed the consumption of ten cigarettes a day; the microfilaria research in the blood and Chlamydia serology were negative, and the exploration of the vascular axis of the lower limbs was normal.

The intervention consisted in a resection of scrotal elephantiasis Taking off all its tunics, and sparing healthy tissue scrotal at the root of purse. The affected penile skin was resected half from a ventral incision with urethrovesical probe in place; the plastic reconstruction used penile and scrotal healthy skin. The postoperative course was uneventful, and the patient was able to resume work and normal Sexual life three months after surgery.

Besides, the histological examination of the surgical specimen concluded a non-filarial idiopathic penoscrotal lymphoedema.

\subsection{Case presentation : 4}

A 60-year-old Berber male was admitted to the Department of Urology with massive scrotal elephantiasis. In fact, the patient had a history of radiotherapy and hormonotherapy for prostate cancer three years ago. The increasing size of his scrotum had made him bed-ridden for the past two years; a suprapubic cystostomy has been performed outside our institution 6 months ago due to residual urine and recurrent urinary tract infections. There was no history of sexual contact, surgery or travel.

During the examination, the patient presented a massively enlarged scrotum extending below his knees. The huge solid verrucous scrotal mass of $23 \times 20 \times 25 \mathrm{~cm}$ made it impossible to differentiate the anatomic structures (figure 1) and the urethral orifice emerged as a deep pit on the anterior surface of the mass. The scrotal skin was thickened and edematous, hiding the penis. No inguinal adenopathy was found. The Testicles and the cords were not found on palpation, with no abnormalities in the ultrasonography. A CT scan of the abdomen showed no evident causes. Also, laboratory testing, including: the human immunodeficiency virus, markers for testicular cancer, antibodies to schistosomes, Chlamydia trachomatis and filariae, were all in the normal range.

Then, we decided to perform a subtotal scrotectomy with preservation of the penis and both Testicles and a reconstruction of the scrotum by rotation flap (figure 2). The histopathologic examination showed non-specific chronic inflammation with areas of epidermal thickening and dermal fibrosis. Finally, wound healing was achieved with acceptable cosmetic results and only a moderate distortion of the penis (figure 3 ).

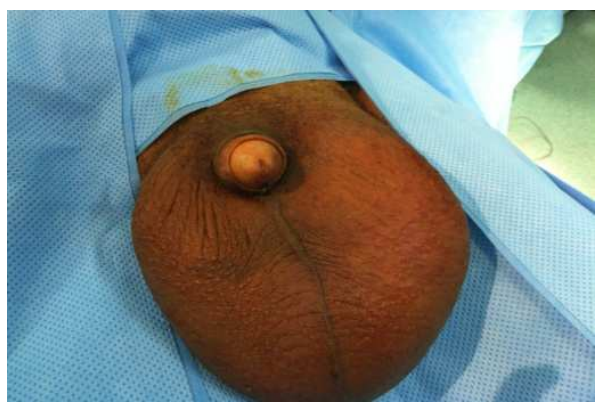

Fig 1. Penoscrotal Elephantiasis.

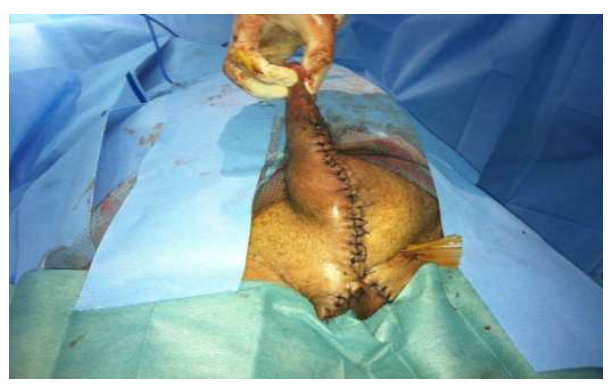

Fig 2. Appearance at the end of surgical treatment.

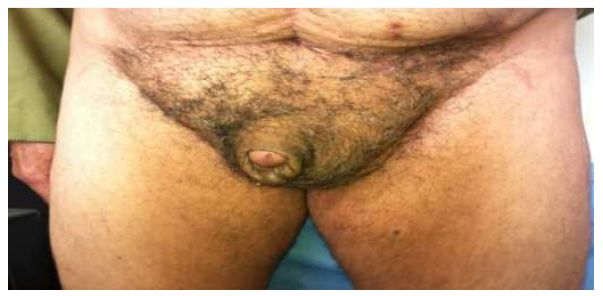

Fig 3. Final appearance eight months after surgical treatment. 


\section{Discussion}

The Penoscrotal Elephantiasis can be defined as "an abnormal collection of fluid that is rich in protein in the subcutaneous tissue, due to an alteration of the local hydrostatic or oncotic pressure". It is most often secondary to a mechanical obstruction of the lymphatic channels either by inflammation and fibrosis, or by filariasis $[1,2]$; it occurs mainly in filariasis-endemic countries [3] and affects especially men from the fourth decade [4], and this predominance reamais unexplained $[3,5]$.

Outside endemic filariasis countries, scrotum elephantiasis is most often idiopathic, rarely congenital or secondary to a sclero-inflammatory stricture of the urethra. The bacterial infections are the cause of endolymphites with obstruction of the vessels, and scrotum elephantiasis would be more important if there is an association of a urethral injury urethral injury $[6,7]$.

The Chlamydia trachomatis infection is the common cause of penoscrotal elephantiasis, but it is still potentially curable [8]. Other etiologies are dominated by acquired lymphangiectasia due to the lymphatic obstruction that is secondary to mechanical or chronic inflammatory disorders, such as a surgical scar, abdominal or pelvic tumor after a pelvic cancer surgery, streptococcal infection, after radiotherapy, sequelae of chronic venous stasis or surgery of urogenital schistosomiasis, Kaposi's sarcoma, or filariasis (Table 1).

Table 1. Etiology of penoscrotal elephantiasis

\begin{tabular}{llll}
\hline- & Congenital & $\bullet$ & Lymphangiomas \\
\hline & & $\bullet$ & Parasitic: Filariasis \\
& & & $\begin{array}{l}\text { Infection: urethral stricture, Chlamydia } \\
\text { trachomatis, Streptococcus }\end{array}$ \\
- Secondary & - & $\begin{array}{l}\text { Tumor: abdominal or pelvic tumor, } \\
\text { Kaposi's sarcoma }\end{array}$ \\
& - & $\begin{array}{l}\text { Iatrogenic radiotherapy, surgery urogenital } \\
\text { schistosomiasis }\end{array}$ \\
\hline
\end{tabular}

The scrotal congenital lymphedema is related to the context of lymphangiomas that are a congenital dysplastic, not regressive dilatations of the lymphatic system. [9]. Elephantiasis Concern most often the scrotum or all penoscrotum, and the isolated penile elephantiasis is rare, but the epididymo-testicular content is always respected [10].

Clinically, the hypertrophy and the deformation of the external genital organ are the main manifestations of the penoscrotal elephantiasis. Besides, the loss of elasticity of the skin has been consistently reported in the literature $[1,6$, and 11].

The Doppler ultrasonography can eliminate an obstacle on the vascular axis of lower limbs; in case of filariasis, it shows adult worms moving in the lymphatic vessels. Bipedal lymphography or radiological isotope shows, sometimes pathognomonic aspects of lymphatic filariasis with lymph blockages storied, lymphangiectasia, and glandular hypertrophy with patchy appearance. Plus, the lymphography also allows the evaluation of the possibility of surgical lymphovenous anastomoses; this technique has its limitations, and there is not always a concordance between lymphographic images and surgical exploration $[12,13]$. The ultrasound, the CT scan, and the MRI can even show a possible compressive origin (pelvic or abdominal tumor) [14]. The retrograde and voiding urethrocystography is requested as soon as a urethral inflammatory stenosis is suspected, when diagnosed, it must imperatively be treated at the same time as the cure of elephantiasis. In addition, the scrotal MRI is a non invasive method, but not essential for this disease. It helps to clarify the limits of surgical resection. The more possible the limited resection is, the easier the scrotal reconstruction will be $[12,15]$. The differential diagnosis (Table 2) arises mainly with inflammatory diseases of the scrotum [10].

Table 2. Differential Diagnostics

\begin{tabular}{|c|c|c|}
\hline $\begin{array}{l}\text { inflammatory } \\
\text { diseases }\end{array}$ & $\begin{array}{ll} & \text { Large } \\
\text { scrotum }\end{array}$ & $\begin{array}{ll} & \text { Systemic } \\
& \text { diseases } \\
\end{array}$ \\
\hline $\begin{array}{ll}\text { - } & \text { Gangrene of the } \\
\text { external genitalia } \\
\text { - } \\
\text { urinous Infiltration of } \\
\text { scrotum } \\
\text { - } \\
\text { epididymo-orchitis } \\
\text { acute idiopathic } \\
\text { scrotal Edema } \\
\text { - } \\
\text { scrotal Edema of } \\
\text { rheumatoid purpura }\end{array}$ & $\begin{array}{ll}\text { - } & \text { Hydrocele } \\
\text { - } & \text { inguinoscrota } \\
& 1 \text { hernia } \\
\text { - } & \text { Pachyvaginal } \\
& \text { ites } \\
\text { - } & \text { Haematocele } \\
\text { - } & \text { Pyocele }\end{array}$ & $\begin{array}{l}\text { edematoascitic } \\
\text { generalized } \\
\text { syndrome }\end{array}$ \\
\hline
\end{tabular}

The surgical treatment proposed in the literature $[16,17]$ consists in excising the mass, extracting all the skin and subcutaneous tissue disease. The Skin Reconstruction is carried out through skin grafts for penis and local flaps of skin for scrotal purse reconstruction.

Some conservative techniques, actually abandoned, have been described, and they aimed at improving the lymphatic drainage: the lymphangioplastie by polyethylene pipes, or lymphatico-venous anastomosis (Nielubowicz operation) between the saphenous vein and the superficial inguinal lymphonodal group [9], but the permeability of the anastomosis is still temporary. [10]

The standard treatment is the surgical excision followed by a scrotal Plastic surgery; so many techniques have been described:

- The use of pedicled skin flaps taken at the inguinal or suprapubic area [5.16]; these flaps are Replaced to cover the scrotal substance loss;

- The use of thin free skin graft [1] that is taken most often from the inner side of the thigh, it is especially recommended for penis recovery with consideration of the risk of graft circular retraction around the penis exposing to aesthetic and functional complications $[1.18,19]$. This method can, however, change the local thermal regulation and induce the testicular disorders of spermatogenesis [6];

- The use of craniodorsal part of the scrotum often allows the neoscrotal reconstruction; the modified 
Botreau-Roussel incision allows a satisfactory scrotal reconstitution, especially in scrotal elephantiasis with penis burying, leaving healthy hypogastric skin that has been stretched by the mass. This method, used by many authors, seems to give a good functional and aesthetic result [1,3, and 16].

The results of this surgery are excellent, with few recurrences due to the lymphatic blockage persistence [16].

\section{Conclusion}

The Penoscrotal Elephantiasis is a rare pathology, which requires complete etiologic investigations to detect mainly a parasitic or a bacterial infection that falls under the medical treatment, the treatment of "troublesome" elephantiasis is always surgical, with an extensive resection of the affected areas and a penoscrotal reconstruction.

\section{Consent}

A written informed consent was obtained from all the patients (case 1, 2, 3, 4) for the publication of this manuscript as well as the accompanying images.

\section{Competing Interests}

All the authors declare that they have no competing interests.

\section{Author's Contribution}

SM, OR: Equal contributors, the principal authors, major contributions in writing the manuscript.

MA, YA, MFT, JEE, AK, MJF, MHF: analyzed and interpreted the patient data and the reviews of the literature.

All authors read and approved the final manuscript.

\section{References}

[1] Ollapallil JJ, Watters DA (1995) surgical management of elephantiasis of male genitalia. Br J Urol 76:213-215

[2] Skoog SJ (1986) verrucous elephantiasis of the scrotum: an unusual variant of genital lymphedema. J Urol 135:799-800

[3] Dandapat MC, Mohapatro SK, Patro SK (1985) Elephantiasis of the penis and scrotum. A review of 350 cases. Am J Surg 149:686-690
[4] Khedroo LG (1976) Reduction perineoplasty for scrotal elephantiasis: a method of surgical reconstruction of the penis and scrotum. J Urol 116:679-680

[5] Apesos J, Anigian G (1991) Reconstruction of penile and scrotal lymphedema. Ann Plast Surg 27:570-573

[6] Sylla C, Ndoye A, Ba M, et al (1998) Penile and scrotal elephantiasis in Senegal. Afr J Urol 4:36-41

[7] Elsahy NI (1976) Syphilitic elephantiasis of the penis and scrotum. Plast Reconstr Surg 57:601-603

[8] Nelson RA, Alberts GL, King LE Jr (2003) Penile and scrotal elephantiasis caused by indolent Chlamydia trachomatis infection. Urology 61:224

[9] Ross JH, Kay R, Yetman RJ, Angermeier K (1998) Primary lymphedema of the genitalia in children and adolescents. J Urol 160:1485-1489

[10] Mianne D, Jacob F (1999) Pathologie inflammatoire du scrotum. EMC Urologie 18-640-A-10

[11] Slama A, Jaidane M, Elleuch A, et al (2002) Traitement chirurgical d'un éléphantiasis pénoscrotal. Prog Urol $12: 337-339$

[12] Arteaga C, Salamand P, Mianne D, et al (1997) Aspects IRM de l'éléphantiasis scrotal filarien : corrélations IRManatomopathologiques. J Radiol 78:1285-1287

[13] Samsoen M, Deschler JM, Servelle M, et al (1981) Le lymphoedème pénoscrotal : deux observations. Ann Dermatol Venerol 108:541-546

[14] Faris S, Hussain O, El Setouhy M, et al (1998) Bancroftian filariasis in Egypt: visualisation of adult worms and subclinical lymphatology by scrotal ultrasound. Am J Trop Med Hyg 56:884-887

[15] Wille S, Niesel T, Breul J, Hartung R (1997) Elephantiasis of the legs with lichen sclerosus and atrophicus of the penis and scrotum. J Urol 157:2262

[16] Ndoye A, Sylla C, Ba M, et al (1999) Point of technique: management of penile and scrotal elephantiasis. BJU Int $84(3): 362-364$

[17] Vignes S, Trevidic $\mathrm{P}$ (2005) Lymphoedèmes pénoscroteaux : étude rétrospective de 33 cas. Ann Dermatol Venereol $132: 21-25$

[18] Holman CM Jr, Arnold PG, Jurkiewicz MJ, Walton KN (1977) Reconstruction of male external genitalia with elephantiasis. Urology 10:576-578

[19] Konety BR, Cooper T, Flood HD, Futrell JW (1996) Scrotal elephantiasis associated with hidradenitis suppurativa. Plast Reconstr Surg 97:1243-1245 